\title{
Standardised neonatal parenteral nutrition formulations - Australasian neonatal parenteral nutrition consensus update 2017
}

Srinivas Bolisetty ${ }^{1,2^{*}}$ D, David Osborn ${ }^{3,4}$, Tim Schindler $^{5}$, John Sinn ${ }^{4,6}$, Girish Deshpande ${ }^{7}$, Chee Sing Wong ${ }^{8}$, Susan E. Jacobs ${ }^{9}$, Nilkant Phad ${ }^{10}$, Pramod Pharande ${ }^{11}$, Rodney Tobiansky ${ }^{12}$, Melissa Luig ${ }^{13}$, Amit Trivedi ${ }^{14}$, Joanne Mcintosh ${ }^{10}$, Eszter Josza ${ }^{1}$, Gillian Opie ${ }^{15}$, Lyn Downe ${ }^{7}$, Chad Andersen ${ }^{16}$, Vineesh Bhatia ${ }^{16}$, Prasanna Kumar ${ }^{17}$, Katri Malinen ${ }^{18}$, Pita Birch ${ }^{19}$, Karen Simmer ${ }^{20}$, Gemma McLeod $^{21}$, Suzanne Quader ${ }^{22}$, Victor Samuel Rajadurai ${ }^{23}$, Michael Patrick Hewson ${ }^{24}$, Arun Nair ${ }^{25}$, Megan Williams ${ }^{11}$, Jing Xiao ${ }^{26}$, Hari Ravindranathan ${ }^{27}$, Roland Broadbent ${ }^{28}$ and Kei Lui ${ }^{29}$

\section{Abstract}

Background: The first consensus standardised neonatal parenteral nutrition formulations were implemented in many neonatal units in Australia in 2012. The current update involving 49 units from Australia, New Zealand, Singapore, Malaysia and India was conducted between September 2015 and December 2017 with the aim to review and update the 2012 formulations and guidelines.

Methods: A systematic review of available evidence for each parenteral nutrient was undertaken and new standardised formulations and guidelines were developed.

Results: Five existing preterm Amino acid-Dextrose formulations have been modified and two new concentrated Amino acid-Dextrose formulations added to optimise amino acid and nutrient intake according to gestation. Organic phosphate has replaced inorganic phosphate allowing for an increase in calcium and phosphate content, and acetate reduced. Lipid emulsions are unchanged, with both SMOFlipid (Fresenius Kabi, Australia) and ClinOleic (Baxter Healthcare, Australia) preparations included. The physicochemical compatibility and stability of all formulations have been tested and confirmed. Guidelines to standardise the parenteral nutrition clinical practice across facilities have also been developed.

Conclusions: The 2017 PN formulations and guidelines developed by the 2017 Neonatal Parenteral Nutrition Consensus Group offer concise and practical instructions to clinicians on how to implement current and up-to-date evidence based PN to the NICU population.

Keywords: Parenteral nutrition, Neonate, Preterm, Standardisation, Consensus

\footnotetext{
* Correspondence: Srinivas.bolisetty@health.nsw.gov.au

${ }^{1}$ Royal Hospital for Women, Locked Bag 2000, Randwick NSW, Sydney 2031,

Australia

${ }^{2}$ Conjoint Lecturer, University of New South Wales, Sydney, Australia

Full list of author information is available at the end of the article
}

(c) The Author(s). 2020 Open Access This article is distributed under the terms of the Creative Commons Attribution 4.0 International License (http://creativecommons.org/licenses/by/4.0/), which permits unrestricted use, distribution, and reproduction in any medium, provided you give appropriate credit to the original author(s) and the source, provide a link to the Creative Commons license, and indicate if changes were made. The Creative Commons Public Domain Dedication waiver (http://creativecommons.org/publicdomain/zero/1.0/) applies to the data made available in this article, unless otherwise stated. 


\section{Background}

Parenteral nutrition (PN) is an essential component in the management of many newborn infants, admitted to Newborn Intensive Care Units (NICUs). All New South Wales (NSW) NICUs and subsequently other Australian NICUs formed a PN Consensus Group in 2010. Formulations were standardised in July 2011 with further amendments in 2012 and 2013. The Consensus Group recommendations and the improved nutritional outcomes following the implementation of consensus formulations were published in 2014 [1, 2]. Although nutritional intakes improved significantly, amino acid targets were not achieved in extremely preterm infants.

\section{Consensus process}

In February 2015, the group reconvened in Sydney, now comprising 49 tertiary and non-tertiary NICUs from Australia, New Zealand, Malaysia, Singapore and India who participated in the consensus meeting in-person or via video link. A survey was conducted to explore the clinical PN practice in each NICU [3]. Outcomes of 2010 consensus formulations were presented, gaps in knowledge identified, topics for updating the formulations prioritised with tasks distributed to participants.

In September 2017, delegates reconvened, evidence was reviewed and guidelines and formulations were updated. A systematic literature search was undertaken and detailed reports were developed for each component of PN. Levels of evidence (LOE) and grades of recommendation (GOR) were allocated according to National Health and Medical Research Council (NHMRC) criteria [4]. Physicochemical compatibility and stability of updated formulations were checked and confirmed compliant by a compounding pharmaceutical facility (Baxter Pharmaceuticals Pty Ltd). The new formulations were commissioned and released in March 2018. The updated PN guidelines are based on the majority consensus of the PN Consensus Group. Where good published evidence was unavailable, recommendations were discussed and, if necessary, voted upon. Time was allowed for thorough literature review, free and open discussion and an exchange of good practice tips among units. Each member of the group was given the opportunity to provide comments and suggestions to the consensus group for their consideration. They are written balancing the potential benefits of PN against associated risks. These practice guidelines do not account for every clinical situation, particularly for infants that are acutely unwell or unstable. The professional judgement of the health professional in these individual cases must take precedence.

\section{Outcomes of the consensus Indications}

The survey of Australian and New Zealand NICUs in 2015 demonstrated that $97 \%$ of extremely preterm infants weighing $<1000 \mathrm{~g}$ and $88 \%$ of very preterm infants $1000-1500 \mathrm{~g}$ are commenced on PN from day 1 of life, and $77 \%$ of NICUs administer PN to any infant $>1500 \mathrm{~g}$ who fails to establish enteral feeds by day 3-5 of life [3]. The current recommendation remains the same as the 2012 recommendation (Table 1 ).

\section{Energy}

Parenteral calorie recommendations remain similar, including consideration of the updated 2014 American Academy of Pediatrics (AAP) Committee on Nutrition recommendation of a parenteral caloric intake of 90$115 \mathrm{kcal} / \mathrm{kg} /$ day in preterm infants [5] and the ESPGHAN 2005 recommendation of $90-110 \mathrm{kcal} / \mathrm{kg} /$ day for extremely low birth weight (ELBW) infants [6].

The 2017 updated starter PN solution infused at $60 \mathrm{ml} / \mathrm{kg} /$ day (33 kcal/kg/day) and new starter concentrated PN solution at $40 \mathrm{ml} / \mathrm{kg} /$ day and lipid emulsion at $1 \mathrm{~g} / \mathrm{kg} /$ day $(10 \mathrm{kcal} / \mathrm{kg} /$ day $)$ provides approximately $43 \mathrm{kcal} / \mathrm{kg} /$ day. The standardised preterm PN solution infused at $135 \mathrm{ml} / \mathrm{kg} /$ day $(70.2 \mathrm{kcal} / \mathrm{kg} /$ day $)$ and new concentrated preterm $\mathrm{PN}$ at $100 \mathrm{ml} / \mathrm{kg} /$ day and lipid emulsion at $3 \mathrm{~g} / \mathrm{kg} /$ day (30 kcal $/ \mathrm{kg} /$ day) provides approximately $100 \mathrm{kcal} / \mathrm{kg} /$ day (Level of Evidence [LOE] II, Grade of Recommendation [GOR] B).

\section{Fluids}

The 2017 consensus agreement is similar to the 2012 recommendation: Standardised PN should be formulated to provide recommended nutrient intakes (RNI) in a total fluid intake of $150 \mathrm{ml} / \mathrm{kg} /$ day. This includes $135 \mathrm{ml} /$ $\mathrm{kg} /$ day of AA/dextrose formulation and $15 \mathrm{ml} / \mathrm{kg} /$ day water in the $20 \%$ lipid emulsion. The 2012 agreement on starting fluid intake at $60 \mathrm{ml} / \mathrm{kg} /$ day with daily increase by $20-30 \mathrm{ml} / \mathrm{kg} /$ day to an average maximum of $150 \mathrm{ml} /$ $\mathrm{kg} /$ day remains. Alternatively, for those units who opt for a total water intake below $150 \mathrm{ml} / \mathrm{kg} /$ day, or unwell babies with multiple non-protein intravenous infusions such as inotropes, opioid analgesics contributing to a significant proportion of fluid volume, the new concentrated PN solutions provide an adequate nutrient and mineral intake on a lower volume.

\section{Amino acids}

There is no definitive evidence about what dose of parenteral amino acid is appropriate and when to initiate parenteral AA supplementation in neonates. Delay in administering amino acids could result in a protein catabolic state and could impact on growth and development in preterm neonates. However, potential benefits of improved nitrogen balance, growth and infant health may be outweighed by the infant's ability to utilise high intakes of parenteral amino acid, especially in the days after birth, resulting in high concentrations of amino 
Table 1 Summary of key recommendations

Key points

Level of evidence (LOE);

Grade of recommendation $(\mathrm{GOR})^{3}$

Indication: Preterm Infants $<32$ weeks and/or $<1500 \mathrm{~g}-\mathrm{PN}$ should be commenced within the first $12 \mathrm{~h}$ of life (on admission).

Consensus

Indication: Infants at high risk of NEC (e.g. absent or reversed foetal umbilical artery flow, perinatal asphyxia) or with illness in whom establishment of enteral feeding is likely to be delayed by 3-5 days.

Consensus

Fluids: Starting parenteral fluid intake at $60 \mathrm{ml} / \mathrm{kg} /$ day with daily increase by $20-30 \mathrm{ml} / \mathrm{kg} /$ day to an average maximum of $150 \mathrm{ml} / \mathrm{kg} /$ day. Titrate to clinical need (urine output and specific gravity, weight, serum sodium).

LOE I

GOR B

Energy: Minimal energy requirements are met with $50-60 \mathrm{kcal} / \mathrm{kg} /$ day, but $100-120 \mathrm{kcal} / \mathrm{kg} /$ day facilitate maximal protein accretion. A newborn infant receiving PN needs fewer calories (90-100 kcal/kg/day) than a

Consensus newborn fed enterally because there is no energy lost in the stools and there is less thermogenesis.

Dextrose: Maximal glucose oxidation has been reported in preterm infants to be $8.3 \mathrm{mg} / \mathrm{kg}$ per min $(12 \mathrm{~g} / \mathrm{kg}$ per day) and in term infants $13 \mathrm{mg} / \mathrm{kg}$ per min ( $18 \mathrm{~g} / \mathrm{kg}$ per day).

Carbohydrate provides $40-60 \%$ of total energy.

Amino acids: (1) commence parenteral AA within the first $24 \mathrm{~h}$ of birth (LOE I, GOR C), (2) commence parenteral $\mathrm{AA}$ at $2 \mathrm{~g} / \mathrm{kg} /$ day (LOE II, GOR C), and

(3) incrementally increase amino acid infusions to a maximum $4 \mathrm{~g} / \mathrm{kg} /$ day by day $3-5$ of life in preterm neonates (LOE I, GOR C).

The safety of (1) commencement parenteral AA in excess of 3 to $3.5 \mathrm{~g} / \mathrm{kg} /$ day and (2) maintenance AA intake in excess of $4.5 \mathrm{~g} / \mathrm{kg} /$ day has not been proven in clinical trials.

Lipids: Commence lipids at $1 \mathrm{~g} / \mathrm{kg} / \mathrm{day}$ and increase by $1 \mathrm{~g}$ each day to $3 \mathrm{~g} / \mathrm{kg} / \mathrm{day}$. If lipid infusion is increased in increments of 0.5 to $1 \mathrm{~g} / \mathrm{kg}$ per day, it may be possible to monitor for hypertriglyceridaemia [triglycerides $>2.8 \mathrm{mmol} / \mathrm{L}]$. Essential fatty acid deficiency occurs rapidly and can be prevented with introduction of as little as 0.5 to $1 \mathrm{~g} / \mathrm{kg} /$ day of lipid infusion [linoleic acid]. Reduce but do not stop lipid infusion in the event of hypertriglyceridaemia.

Sodium: Minimal sodium intake of approximately $1 \mathrm{mmol} / \mathrm{kg} /$ day on day 1 using a starter PN formulation. Standard formulations will gradually increase sodium to a maximum $4.6 \mathrm{mmol} / \mathrm{kg} / \mathrm{d}$ in preterm and $3.4 \mathrm{mmol} / \mathrm{kg} /$ day in term infants at $135 \mathrm{ml} / \mathrm{kg} /$ day of PN.

Potassium: Minimal potassium intake using starter PN formulation, with an increase in standard formulations to a maximum $3.0 \mathrm{mmol} / \mathrm{kg} /$ day in preterm and $2.7 \mathrm{mmol} / \mathrm{kg} /$ day in term infants.

Acetate and chloride: First $3 \mathrm{mmol} / \mathrm{kg} /$ day of anion to be provided as chloride, next $3.5 \mathrm{mmol} / \mathrm{kg} / \mathrm{day}$ of anion [reduced from $6 \mathrm{mmol} / \mathrm{kg} / \mathrm{day}$ ] to be provided as acetate and thereafter as chloride again.

Calcium, phosphorus and magnesium: Parenteral $\mathrm{Ca}$ and $\mathrm{P}$ intakes to a maximum of $2.3 \mathrm{mmol} / \mathrm{kg} / \mathrm{day}$ and $1.8 \mathrm{mmol} / \mathrm{kg} /$ day respectively. LOE II

For Mg intake a minimum of $0.2 \mathrm{mmol} / \mathrm{kg} /$ day and maximum of $0.3 \mathrm{mmol} / \mathrm{kg} /$ day is appropriate for LBW infants. LOE $111-3$

Trace elements: Add zinc, selenium and iodine as individual trace elements to all AA/dextrose formulations. For those infants, who are on exclusive PN for more than 2 to 4 weeks with minimal enteral intake, other trace elements (copper, manganese and molybdenum) can be added to the formulations.

Heparin: Heparin for peripherally placed percutaneous central venous catheters found a reduced risk of catheter occlusion.

Hanging time: $48 \mathrm{~h}$ for PN solution and lipid.

Route of administration: Peripherally inserted central catheters (PICC's) should be used preferentially to provide central venous access in neonates receiving prolonged PN as PICC use results in improved nutrient intake, fewer insertion attempts and fewer extravasation injuries.

Umbilical vessels can be used for PN. UVC compared to peripheral venous catheter reduces insertion attempts with no increase in risk of infection or necrotising enterocolitis.

Cessation of PN:

Amino acid/dextrose infusion: cease when infant tolerating 120 (to 140 ) $\mathrm{mL} / \mathrm{kg} /$ day of enteral feeds Lipid: halve infusion when infant tolerating $100 \mathrm{~mL} / \mathrm{kg} /$ day enteral feeds and cease when tolerating $120 \mathrm{~mL} / \mathrm{kg} /$ day enteral feeds.

acids, ammonia and urea, and an exacerbation of metabolic acidosis. The 2017 consensus agreement incorporates the findings of three new systematic reviews that evaluated the efficacy and safety of parenteral AA in preterm neonates [7-9].
The Consensus Group recommendations remained unchanged: (1) commence parenteral AA within the first $24 \mathrm{~h}$ of birth (LOE I, GOR C); (2) commence parenteral $\mathrm{AA}$ at $2 \mathrm{~g} / \mathrm{kg} /$ day (LOE I, GOR C) and; (3) incrementally increase amino acid infusions to a maximum $4 \mathrm{~g} / \mathrm{kg} /$ day 
by day 3-5 of life in preterm neonates (LOE I, GOR C). The Consensus Group considered the safety of (1) commencement parenteral AA in excess of 3 to $3.5 \mathrm{~g} / \mathrm{kg} /$ day and (2) maintenance AA intake in excess of $4.5 \mathrm{~g} / \mathrm{kg} /$ day has not been proven in clinical trials.

\section{Carbohydrates}

Consensus recommendations regarding carbohydrates remain unchanged. Proposed standard preterm and term PN formulations contain 10 and $12 \%$ dextrose respectively, providing $13.5 \mathrm{~g} / \mathrm{kg} /$ day $(9.4 \mathrm{mg} / \mathrm{kg} / \mathrm{min})$ and $17 \mathrm{~g} / \mathrm{kg} / \mathrm{day}$ $(11.8 \mathrm{mg} / \mathrm{kg} / \mathrm{min}$ ) at $135 \mathrm{ml} / \mathrm{kg} /$ day respectively (LOE I, GOR C).

\section{Lipids}

The Consensus Group reconsidered the findings of two systematic reviews, which reported no benefit of introducing lipids before two to five days [10, 11]. As the composition of growth was not assessed in these studies, it is uncertain if increased energy intake derived from early lipid infusion is protective against induced protein catabolism in the preterm neonate. Further, it is possible to prevent essential fatty acid deficiency with introduction of as little as 0.5 to $1 \mathrm{~g} / \mathrm{kg} /$ day of lipid (linoleic acid) infusion [10]. The Consensus Group agreed to commencement of parenteral lipid on day 1 of PN administration, particularly for extremely preterm neonates (LOE I, GOR C).

Several types of intravenous lipid emulsions (IVLE) are available for neonatal use. Recent systematic reviews have shown no statistically significant differences between IVLEs with respect to clinically important outcomes including mortality, growth, chronic lung disease, sepsis, severe ROP $\geq$ stage 3 , and cholestasis by using any specific preparation in newborns [12-14] (LOE I, GOR C). The 2015 Survey revealed $67 \%$ of units in ANZ use both mixed 30\% soybean oil/25\% olive oil/ $30 \%$ medium-chain triglyceride oil/15\% fish oil IVLE (SMOFlipid [Fresenius Kabi, Australia]) and mixed 80\% olive oil/20\% soybean oil IVLE (ClinOleic [Baxter Healthcare, Australia]) [3]. All units use water and fat soluble vitamins added to lipid emulsion. The consensus 2017 proposed both SMOFlipid and ClinOleic as suitable lipid preparations and anticipate individual units will take cost and waste minimisation into consideration when choosing the specific type of lipid preparation most suited to their needs.

All lipid emulsions with added fat and water soluble vitamins discussed above are formulated to provide $1 \mathrm{~g}$ of lipid (SMOFlipid or ClicOleic) in $6 \mathrm{~mL}$ of lipid emulsion with vitamins (Soluvit $\mathrm{N}$ and Vitalipid $\mathrm{N}$ Infant). Thus, $1 \mathrm{~g}$ lipid $/ \mathrm{kg} /$ day equates to $6 \mathrm{~mL}$ lipid emulsion with vitamins $/ \mathrm{kg} / \mathrm{d}$, which equates to an energy intake of $10 \mathrm{kcal} / \mathrm{kg} /$ day. Similarly, $2 \mathrm{~g}$ lipid $/ \mathrm{kg} /$ day equates to $12 \mathrm{ml} / \mathrm{kg} /$ day lipid emulsion with vitamins and $3 \mathrm{~g}$ lipid/ $\mathrm{kg} /$ day equates to $18 \mathrm{ml} / \mathrm{kg} /$ day lipid emulsion with vitamins. There are variations in terms of starting dose of lipid emulsions. However, a starting dose $1 \mathrm{~g} / \mathrm{kg} /$ day was safely tolerated in most clinical trials. The consensus agreed to commence lipids at $1 \mathrm{~g} / \mathrm{kg} / \mathrm{day}$. There is no evidence that gradual increments in the infusion rate of lipids improve fat tolerance. The majority consensus was to increase by $1 \mathrm{~g} / \mathrm{kg}(6 \mathrm{~mL} / \mathrm{kg})$ each day to $3 \mathrm{~g} / \mathrm{kg} /$ day $(18 \mathrm{~mL} / \mathrm{kg} /$ day). If lipid infusion is increased in increments of 0.5 to $1.0 \mathrm{~g} / \mathrm{kg} /$ day, it may be possible to monitor for hypertriglyceridemia [6]. The lipid emulsions contain $80 \%$ water $(6 \mathrm{~mL}$ lipid emulsion with vitamins contains $5 \mathrm{~mL}$ water; $12 \mathrm{~mL}$ lipid emulsion with vitamins contains $10 \mathrm{~mL}$ water; $18 \mathrm{~mL}$ lipid emulsion with vitamins contains $15 \mathrm{~mL}$ water). In view of benefits associated with restricted fluid intake [15], the group proposed to include the water content of lipid infusions in the total fluid intake, which equates to $15 \mathrm{ml} / \mathrm{kg} /$ day of water when the lipid intake reaches $3 \mathrm{~g} / \mathrm{kg} /$ day (LOE I, GOR B).

\section{Sodium, potassium and chloride}

The 2017 consensus reaffirmed the consensus reached in 2012, agreeing to minimal sodium intake of approximately $1 \mathrm{mmol} / \mathrm{kg} / \mathrm{d}$ on day 1 using a starter PN formulation. Sodium in starter formulation is a component of organic phosphate (sodium glycerophosphate which contains $2 \mathrm{mmol} \mathrm{Na}$ per mmol of phosphate) and can only be altered by replacing with other sodium free nutrients. The currently designed starter and standard formulations will increase sodium from $1 \mathrm{mmol} / \mathrm{kg} /$ day on day 1 (starter formulation) to a maximum $4.6 \mathrm{mmol} / \mathrm{kg} /$ day in preterm infants and $3.4 \mathrm{mmol} / \mathrm{kg} /$ day in term infants at $135 \mathrm{ml} / \mathrm{kg} /$ day (standard formulations) (LOE II, GOR C). The new starter concentrated PN solutions will gradually increase sodium from $1.2 \mathrm{mmol} / \mathrm{kg} /$ day on day 1 in the starter concentrated $\mathrm{PN}$ to a maximum 5.0 $\mathrm{mmol} / \mathrm{kg} /$ day in the concentrated preterm $\mathrm{PN}$ in extremely preterm infants. A Cochrane review assessing the benefits and harms of higher versus lower sodium intakes in preterm infants is currently underway [16].

The Consensus Group agreed on minimal potassium intake using starter PN formulation, with an increase in standard formulations to a maximum $3.0 \mathrm{mmol} / \mathrm{kg} / \mathrm{d}$ in preterm and $2.7 \mathrm{mmol} / \mathrm{kg} /$ day in term infants (LOE III2, GOR C). This is unchanged from the previous consensus and complies with AAP and ESPGHAN 2005 recommendations $[5,6]$.

With respect to chloride, the 2013 consensus was to adopt a trial recommendation that the first $3 \mathrm{mmol} / \mathrm{kg} /$ day of anion is provided as chloride, next $6 \mathrm{mmol} / \mathrm{kg} /$ day of anion is provided as acetate and thereafter as chloride again [17]. However, there have been concerns about hypercarbia in some infants using 2013 formulations. Moreover, 2017 
consensus formulations contain organic phosphate (sodium glycerophosphate) resulting in an increase of $\mathrm{pH}$ of the formulations. Therefore, the 2017 consensus is to reduce the acetate content to a maximum of $3.5 \mathrm{mmol} / \mathrm{kg} /$ day in the updated standard formulations (LOE II, GOR C).

\section{Calcium, phosphorus and magnesium}

There is a wide range in the recommended doses of calcium $(\mathrm{Ca})$ and phosphorus $(\mathrm{P})$ delivered by $\mathrm{PN}$ in preterm infants. American Academy of Pediatrics 2014 recommends $1.5-2.0 \mathrm{mmol} / \mathrm{kg} / \mathrm{day}$ of $\mathrm{Ca}$ and $1.5-1.9 \mathrm{mmol} / \mathrm{kg} / \mathrm{day}$ of phosphorus whereas ESPGHAN 2005 recommends $1.3-3 \mathrm{mmol} / \mathrm{kg} /$ day of $\mathrm{Ca}$ and $1.0-2.3 \mathrm{mmol} / \mathrm{kg} /$ day of $\mathrm{P}$, with optimal $\mathrm{Ca}: \mathrm{P}$ ratio between 1.3-1.7 [5, 6]. However, these recommendations are based on in-utero accretion rates. While a number of clinical studies evaluated the efficacy and safety of various parenteral intakes of $\mathrm{Ca}$ and $\mathrm{P}$ in preterm infants, none of them tested the ESPGHAN recommended maximum intake levels of $3 \mathrm{mmol} / \mathrm{kg} /$ day of $\mathrm{Ca}$ and $2.3 \mathrm{mmol} / \mathrm{kg} /$ day of $\mathrm{P}$ in preterm neonates, so the safety of this level of intake is unreported [18-21]. One RCT used inorganic phosphate for an estimated maximum $\mathrm{P}$ intake $2.6 \mathrm{mmol} / \mathrm{kg} /$ day with a maximal $\mathrm{Ca}$ intake $2 \mathrm{mmol} / \mathrm{kg} /$ day [20].

Until recently, only inorganic phosphate has been registered by Therapeutics Goods Administration Australia and higher intakes of calcium and phosphate intravenously were not possible while maintaining compatibility to prevent calcium-phosphate precipitation $[20,21]$. Recently, organic phosphate in the form of sodium glycerophosphate has been registered. Substitution of inorganic phosphate by organic phosphate improves physicochemical compatibility with trial evidence reported increased mineral intake and mineral retention [19].

Due to a paucity of studies on the safety of maximum parenteral RDIs for $\mathrm{Ca}$ and $\mathrm{P}$ and the availability of organic phosphate with improved physicochemical stability, the 2017 consensus increased the parenteral Ca and $\mathrm{P}$ intakes to a maximum of $2.3 \mathrm{mmol} / \mathrm{kg} /$ day and $1.8 \mathrm{mmol} / \mathrm{kg} /$ day respectively. Furthermore, there is additional $0.19 \mathrm{mmol} / \mathrm{kg} /$ day P from ClinOleic or SMOFLipid at $3 \mathrm{~g} / \mathrm{kg} /$ day.

The 2017 consensus regarding magnesium $(\mathrm{Mg})$ is unchanged. A minimum $\mathrm{Mg}$ intake of $0.2 \mathrm{mmol} / \mathrm{kg} /$ day and maximum $0.3 \mathrm{mmol} / \mathrm{kg} /$ day is considered appropriate for LBW infants. (LOE III-3, GOR C).

\section{Vitamins}

The lipid emulsion contains water and fat soluble vitamins (Soluvit $\mathrm{N}$ and Vitalipid $\mathrm{N}$ Infant [Fresenius Kabi, Australia]). There was no change with respect to vitamins in the 2017 consensus.

\section{Trace elements}

In the absence of a formulation with the optimal mixture of trace elements, the 2012 consensus was to add zinc, selenium and iodine as individual trace elements to all AA/dextrose formulations. Trace elements were not added to the starter formulation due to physicochemical compatibility concerns. The 2018 formulations contain organic phosphate allowing addition of trace elements in all formulations including the starter formulation without any physicochemical instability. Other trace elements, including copper, manganese and molybdenum, can be added to the formulations in infants who are on exclusive PN for more than 2-4 weeks with minimal enteral intake.

\section{Heparin}

Our previous and current consensus is to add heparin $0.5 \mathrm{IU} / \mathrm{ml}$ to $\mathrm{AA} /$ dextrose formulations (LOE I, GOR C) and remains the same.

\section{Physicochemical stability}

Physicochemical stability of the latest formulations have been tested and confirmed to be stable for up to 61 days at $2-8{ }^{\circ} \mathrm{C}$ and 5 days at below $25^{\circ} \mathrm{C}$ (Baxter Healthcare, Australia).

\section{Hanging time}

The majority consensus 2017 recommended a hanging time of $48 \mathrm{~h}$ for PN solution. Due to concerns of microbial contamination with longer hanging times [22-24], a range of 24-48 hanging time was agreed for lipid infusions (LOE II, GOR C).

\section{Route of administration}

Umbilical catheters In neonates, umbilical vessels can be used for PN [6]. Umbilical venous catheters compared to peripheral venous catheter reduces insertion attempts with no increase in risk of infection or necrotising enterocolitis [25]. The risk of complication may increase if umbilical venous catheters are left in place for more than 14 days [26, 27].

Central cannula Peripherally inserted central catheters (PICCs) should be used preferentially to provide central venous access in neonates receiving prolonged $\mathrm{PN}$ as PICC use results in improved nutrient intake and fewer insertion attempts $[6,28]$.

Peripheral cannula As phlebitis of peripheral veins were reported when the osmolality of the intravenous solution exceeded $600 \mathrm{mOsm}$ [29], peripheral veins have been recommended for short term venous access [6, 29]. The group has developed a peripheral preterm PN 
solution (see below) with reduced mineral content that can be used to run through the peripheral cannula for short periods of time, although there is limited evidence for the role of minerals in the development of tissue injury. Although extravasation injury occurs in up to $10 \%$ of infants managed only with peripheral infusion of PN [28], it is unclear if the risk of peripheral PN is greater than the risk of peripheral crystalloid infusion.

\section{Osmolality}

The formulations that have been developed as a result of the 2017 consensus are predominantly intended for administration via a central vein. American Society of Parenteral and Enteral Nutrition (ASPEN) recommends the osmolarity of peripheral parenteral nutrition solutions be limited to $900 \mathrm{mOsm} / \mathrm{L}$ to lower the risk of phlebitis due to infiltration based on a study that evaluated the feasibility of infusing a $900 \mathrm{mOsm} / \mathrm{L}$ solution through peripheral veins in 15 adult participants [30]. A prospective study reported that administration of PN with an osmolarity $\leq 1000 \mathrm{mOsm} / \mathrm{L}$ resulted in an $8 \%$ (15 of 181) incidence of extravasation/phlebitis, whereas peripheral administration of PN with osmolarity $>1000$ $\mathrm{mOsm} / \mathrm{L}$ resulted in a 30\% (40 of 134) incidence of extravasation/phlebitis, suggesting that peripheral administration of PN in neonates should be limited to 1000 $\mathrm{mOsm} / \mathrm{L}$. [31] Another retrospective, matched-cohort study that included 151 neonates found that administration of PN with osmolarity $>1000 \mathrm{mOsm} / \mathrm{L}$ vs $\leq 1000$ $\mathrm{mOsm} / \mathrm{L}$ significantly increased infiltration $(17 \%$ vs $7 \%$; odds ratio $[\mathrm{OR}], 2.47 ; 95 \%$ confidence interval [CI], $1.24-4.94 ; P=.01)$ and the combined composite end point of phlebitis or infiltration (45\% vs $34 \%$; OR, 1.65; 95\% CI, 1.07-2.54; $P=.02$ ). In multivariate analysis, osmolarity > $1000 \mathrm{mOsm} / \mathrm{L}$ vs $\leq 1000 \mathrm{mOsm} / \mathrm{L}$ was an independent risk factor for developing complications (OR, 1.67; 95\% CI, 1.08-2.52; $P=.02$ ) [32].

The 2017 Consensus Group concluded that PN solutions with osmolality below $1000 \mathrm{mosm} / \mathrm{L}$ can be administered peripherally for short term use provided that close monitoring of the IV site for any extravasation/ phlebitis is followed. In view of the dearth of evidence, the group agreed to continue the peripheral PN formulation in case of concerns regarding the amount of calcium infused through peripheral veins.

\section{$P N$ in late preterm $\left(34^{+0}\right.$ to $36^{+6}$ weeks) and term neonates}

There is paucity of data on the efficacy and safety of PN in this age group. Two small studies enrolled late preterm and term neonates, but neither reported on major clinical outcomes [33, 34]. PN is widely used in Australian facilities in late preterm and term neonates who are not enterally fed. The 2017 Consensus Group followed the human milk approach to develop the PN formulations for this group and nutrient intake estimates are based on the average composition and intake of human milk [35].

\section{Updated consensus formulations}

Table 1 provides the summary of recommendations and strength of evidence for recommendations. Based on these recommendations, the 2017 group developed 8 $\mathrm{AA} /$ dextrose formulations and 2 lipid formulations in different volumes. Six of these AA/dextrose formulations are the improved versions of 2012 formulations. These are summarised in Table 2. Two new AA/dextrose formulations have been proposed and the contents and indications of these formulations are shown in Tables 3-4. Suggested lipid formulations are shown in Table 5. Additional file 1: Tables S1 and S2 show the nutrient intakes provided by the standard formulations in comparison to the recommended nutrient intakes (RNI).

\section{Cessation of PN}

AA/dextrose infusion There is no clear evidence to guide practice. The risk of late onset sepsis with intravenous access and the cost of $\mathrm{PN}$ are to be considered. The 2015 consensus survey found the majority of the NICUs in ANZ cease AA/dextrose formulation once the infant tolerates $120-140 \mathrm{ml} / \mathrm{kg} /$ day of enteral feeds [3].

Lipids Mature human milk contains $3.4 \mathrm{~g}$ of fat per $100 \mathrm{~mL}$. The 2015 consensus survey reported that the majority of NICUs cease IV lipids once the infant tolerates $100-120 \mathrm{~mL} / \mathrm{kg} /$ day of enteral feeds [3].

\section{Biochemical monitoring on PN}

PN administration requires careful clinical and laboratory monitoring. High blood urea nitrogen, hyperglycaemia, metabolic acidosis, hypertriglyceridemia and conjugated hyperbilirubinemia are frequently encountered biochemical abnormalities on PN. In addition to routine observations, periodic measurements of the following biochemical parameters are suggested during PN therapy. Suggested monitoring by the group is shown in Additional file 1: Table S3.

No data are available to determine the effect of higher versus lower amino acid and lipid intake in PN in 'sick' infants (e.g., infants with moderate-severe respiratory distress, receiving cardiovascular support, possible sepsis, acidosis); and 'surgical' or postoperative infants or infants post-cardiopulmonary bypass.

Blood Urea Nitrogen [Conversion blood urea nitrogen $=$ blood urea divided by 2.14]: In the Cochrane review comparing higher versus lower amino acid intake in parenteral nutrition, six studies reported BUN levels [9]. The criteria for abnormal blood urea nitrogen 
Table 2 Updated Amino acid-dextrose formulations

\begin{tabular}{|c|c|c|c|c|c|c|}
\hline PN & Starter & Standard Preterm & High Sodium & 7.5\% Glucose Preterm & Peripheral preterm & 34 weeks to Term \\
\hline Indication & Birth to $24-48 \mathrm{~h}$ & After $24-48 \mathrm{~h}$ & Hyponatraemic Preterm & Hyperglycaemic Preterm & No central line & After 24-48 h \\
\hline \multicolumn{7}{|l|}{ Concentration per litre } \\
\hline$A A, g$ & 37.5 & 30 & 30 & 30 & 30 & 23 \\
\hline Dextrose, $g$ & 100 & 100 & 100 & 75 & 100 & 120 \\
\hline $\mathrm{Na}, \mathrm{mmol}$ & 20 & 34 & 60 & 34 & 34 & 25 \\
\hline $\mathrm{K}, \mathrm{mmol}$ & 0 & 22 & 22 & 22 & 22 & 20 \\
\hline $\mathrm{Ca}, \mathrm{mmol}$ & 17 & 17 & 17 & 17 & 3.5 & 7 \\
\hline Mg, mmol & 1.5 & 1.5 & 1.5 & 1.5 & 1.5 & 1.5 \\
\hline $\mathrm{P}, \mathrm{mmol}$ & 10 & 13 & 13 & 13 & 3 & 4 \\
\hline $\mathrm{Cl}, \mathrm{mmol}$ & 10.1 & 12.7 & 30.7 & 12.7 & 18.7 & 28.2 \\
\hline Acetate, mmol & 0 & 26 & 34 & 26 & 40 & 16.2 \\
\hline Zinc, $\mu \mathrm{g}$ & 3270 & 3270 & 3270 & 3270 & 3270 & 1900 \\
\hline Selenium, $\mu \mathrm{g}$ & 20 & 20 & 20 & 20 & 20 & 20 \\
\hline lodine, $\mu \mathrm{g}$ & 8.16 & 8.16 & 8.16 & 8.16 & 8.16 & 8.16 \\
\hline Heparin, units & 500 & 500 & 500 & 500 & 500 & 500 \\
\hline Osmolarity, mosm & 933 & 944 & 996 & 805 & 913 & 957 \\
\hline \multicolumn{7}{|c|}{ Nutrient intake when infused at $135 \mathrm{ml} / \mathrm{kg} /$ day } \\
\hline$A A, g$ & & 4.1 & 4.1 & 4.1 & 4.1 & 3.1 \\
\hline Dextrose, $g$ & & 13.5 & 13.5 & 10.1 & 13.5 & 16.2 \\
\hline $\mathrm{Na}, \mathrm{mmol}$ & & 4.6 & 8.1 & 4.6 & 4.6 & 3.4 \\
\hline $\mathrm{K}, \mathrm{mmol}$ & & 3.0 & 3.0 & 3.0 & 3.0 & 2.7 \\
\hline $\mathrm{Ca}, \mathrm{mmol}$ & & 2.3 & 2.3 & 2.3 & 0.5 & 0.9 \\
\hline $\mathrm{Mg}, \mathrm{mmol}$ & & 0.2 & 0.2 & 0.2 & 0.2 & 0.2 \\
\hline $\mathrm{P}, \mathrm{mmol}$ & & 1.8 & 1.8 & 1.8 & 0.4 & 0.5 \\
\hline $\mathrm{Cl}, \mathrm{mmol}$ & & 1.7 & 4.1 & 1.7 & 2.5 & 3.8 \\
\hline Acetate, mmol & & 3.5 & 4.6 & 3.5 & 5.4 & 2.2 \\
\hline Zinc, $\mu \mathrm{g}$ & & 441 & 441 & 441 & 441 & 257 \\
\hline Selenium, $\mu \mathrm{g}$ & & 2.7 & 2.7 & 2.7 & 2.7 & 2.7 \\
\hline lodine, $\mu \mathrm{g}$ & & 1.1 & 1.1 & 1.1 & 1.1 & 1.1 \\
\hline
\end{tabular}

differed between the studies and varied from $>10 \mathrm{mmol} /$ $\mathrm{L}$ to $21.4 \mathrm{mmol} / \mathrm{L}$. There was a significant increase in abnormal blood urea nitrogen level from higher amino acid intake in all these studies although a threshold level was not clear. Given the data supporting the importance of early amino-acid administration in premature infants, limiting amino acid intake based on serum BUN alone is not warranted. BUN levels up to $14.3 \mathrm{mmol} / \mathrm{L}$ may be considered acceptable in VLBW infants on PN provided there are no other parameters to suggest protein intolerance (eg hyperammonaemia $>122 \mu \mathrm{mol} / \mathrm{L}$ ) [9].

Hyperglycaemia Hyperglycaemia $(>8.3 \mathrm{mmol} / \mathrm{L})$ is not uncommon in ELBW infants [36]. If blood glucose $>10 \mathrm{mmol} / \mathrm{L}$ (moderate hyperglycaemia) [37, 38], further management to control hyperglycaemia should be considered including reducing the glucose infusion rate (e.g. changing over to $7.5 \%$ Dextrose $\mathrm{PN}$ ).

Hypoglycaemia $(\mathrm{BGL}<2.6 \mathrm{mmol} / \mathrm{L}) \quad[39,40]$ can occur particularly with a sudden cessation of $\mathrm{PN}$ or undetected extravasation of solutions.

Cholestasis Defined as serum level of direct bilirubin > $20 \%$ of total serum bilirubin or serum level of direct bilirubin $>34 \mathrm{mmol} / \mathrm{L}[\mathrm{mg} / \mathrm{dL} \times 17.10]$ [41]

Hypoalbuminemia Defined as serum albumin, preterm $<18 \mathrm{~g} / \mathrm{L}$ in preterm $[42,43]$ and $<25 \mathrm{~g} / \mathrm{L}$ in term neonates [43].

Hypertriglyceridemia (HT) (plasma triglyceride $>\mathbf{2 . 8}$ mmol/L) ESPGHAN 2005 Guidelines recommend 
Table 3 New Starter Concentrated AA/dextrose formulation

\begin{tabular}{|c|c|c|c|c|c|c|}
\hline & $\begin{array}{l}\text { For preterm ir } \\
\text { Not recomme }\end{array}$ & $\begin{array}{l}\text { restric } \\
\text { rate }>\end{array}$ & ter in & $24-48$ & & \\
\hline & per $1000 \mathrm{~mL}$ & $\mathrm{~mL} / \mathrm{k}$ & & & & \\
\hline & & 40 & 50 & 60 & 70 & 80 \\
\hline$A A, g$ & 50 & 2.0 & 2.5 & 3.0 & 3.5 & 4.0 \\
\hline Dextrose, $\mathrm{g}$ & 100 & 4.0 & 5.0 & 6.0 & 7.0 & 8.0 \\
\hline $\mathrm{Na}, \mathrm{mmol}$ & 30 & 1.2 & 1.5 & 1.8 & 2.1 & 2.4 \\
\hline $\mathrm{K}, \mathrm{mmol}$ & 0 & 0.0 & 0.0 & 0.0 & 0.0 & 0.0 \\
\hline $\mathrm{Ca}, \mathrm{mmol}$ & 25 & 1.0 & 1.3 & 1.5 & 1.8 & 2.0 \\
\hline $\mathrm{Mg}, \mathrm{mmol}$ & 1.5 & 0.1 & 0.1 & 0.1 & 0.1 & 0.1 \\
\hline $\mathrm{P}, \mathrm{mmol}$ & 15 & 0.6 & 0.8 & 0.9 & 1.1 & 1.2 \\
\hline $\mathrm{Cl}, \mathrm{mmol}$ & 12.5 & 0.5 & 0.6 & 0.8 & 0.9 & 1.0 \\
\hline Acetate, mmol & 0 & 0.0 & 0.0 & 0.0 & 0.0 & 0.0 \\
\hline Zinc, $\mu \mathrm{g}$ & 3270 & 131 & 164 & 196 & 229 & 262 \\
\hline Selenium, $\mu \mathrm{g}$ & 20 & 0.8 & 1.0 & 1.2 & 1.4 & 1.6 \\
\hline lodine, $\mu \mathrm{g}$ & 8.16 & 0.3 & 0.4 & 0.5 & 0.6 & 0.7 \\
\hline Heparin, units & 500 & 20 & 25 & 30 & 35 & 40 \\
\hline Osmolarity, mosm/L & 1069 & & & & & \\
\hline Solution $\mathrm{pH}$ & 5.69 & Alert & nal sta & intake & & \\
\hline Bag volume, $\mathrm{mL}$ & 500 & Stab & ays @ & ys at b & & \\
\hline
\end{tabular}

Table 4 New concentrated preterm AA/dextrose formulation

\begin{tabular}{|c|c|c|c|c|c|c|c|c|c|}
\hline & \multicolumn{9}{|c|}{$\begin{array}{l}\text { For preterm infants with restricted PN or water intake after } 24-48 \mathrm{~h} \text {. } \\
\text { Not recommended at rate }>100 \mathrm{ml} / \mathrm{kg} / \text { day. }\end{array}$} \\
\hline & \multirow[t]{2}{*}{ per $1000 \mathrm{~mL}$} & \multicolumn{8}{|c|}{$\mathrm{mL} / \mathrm{kg} /$ day } \\
\hline & & 40 & 50 & 60 & 70 & 80 & 90 & 100 & 110 \\
\hline Amino acids, g & 40 & 1.6 & 2.0 & 2.4 & 2.8 & 3.2 & 3.6 & 4.0 & 4.4 \\
\hline Dextrose, g & 100 & 4.0 & 5.0 & 6.0 & 7.0 & 8.0 & 9.0 & 10.0 & 11.0 \\
\hline $\mathrm{Na}, \mathrm{mmol}$ & 50 & 2.0 & 2.5 & 3.0 & 3.5 & 4.0 & 4.5 & 5.0 & 5.5 \\
\hline $\mathrm{K}, \mathrm{mmol}$ & 35 & 1.4 & 1.8 & 2.1 & 2.5 & 2.8 & 3.2 & 3.5 & 3.9 \\
\hline $\mathrm{Ca}, \mathrm{mmol}$ & 22 & 0.9 & 1.1 & 1.3 & 1.5 & 1.8 & 2.0 & 2.2 & 2.4 \\
\hline $\mathrm{Mg}, \mathrm{mmol}$ & 1.5 & 0.1 & 0.1 & 0.1 & 0.1 & 0.1 & 0.1 & 0.2 & 0.2 \\
\hline $\mathrm{P}, \mathrm{mmol}$ & 15 & 0.6 & 0.8 & 0.9 & 1.1 & 1.2 & 1.4 & 1.5 & 1.7 \\
\hline $\mathrm{Cl}, \mathrm{mmol}$ & 39.6 & 1.6 & 2.0 & 2.4 & 2.8 & 3.2 & 3.6 & 4.0 & 4.4 \\
\hline Acetate, mmol & 26 & 1.0 & 1.3 & 1.6 & 1.8 & 2.1 & 2.3 & 2.6 & 2.9 \\
\hline Zinc, $\mu \mathrm{g}$ & 4900 & 196 & 245 & 294 & 343 & 392 & 441 & 490 & 539 \\
\hline Selenium, $\mu \mathrm{g}$ & 30 & 1.2 & 1.5 & 1.8 & 2.1 & 2.4 & 2.7 & 3.0 & 3.3 \\
\hline lodine, $\mu \mathrm{g}$ & 12 & 0.5 & 0.6 & 0.7 & 0.8 & 1.0 & 1.1 & 1.2 & 1.3 \\
\hline Heparin, units & 500 & 20 & 25 & 30 & 35 & 40 & 45 & 50 & 55 \\
\hline Osmolarity, mOsm/L & 1092 & \multicolumn{8}{|c|}{ Alert - below minimal recommended maintenance AA if no enteral intake } \\
\hline Solution $\mathrm{pH}$ & 5.75 & \multicolumn{8}{|c|}{ Alert - above maximal recommended calcium and amino acid intake } \\
\hline Bag volume, $\mathrm{mL}$ & 750 & \multicolumn{8}{|c|}{ Stability: up to 61 days @ $2-8{ }^{\circ} \mathrm{C}$ and 5 days at below $25^{\circ} \mathrm{C}$. } \\
\hline
\end{tabular}


Table 5 Lipid/vitamin admixtures

\begin{tabular}{|c|c|c|c|}
\hline \multicolumn{4}{|c|}{ SMOFLipid (Fresenius Kabi, Australia) formulations } \\
\hline Contents & $\begin{array}{l}45 \mathrm{~mL} \text { syringe } \\
\text { For } \leq 1 \mathrm{Kg}\end{array}$ & $90 \mathrm{~mL}$ bag - Unavailable & $\begin{array}{l}145 \mathrm{~mL} \text { bag } \\
\text { For }>1 \mathrm{Kg}\end{array}$ \\
\hline SMOFlipid & $32.5 \mathrm{~mL}$ & & $100 \mathrm{~mL}$ \\
\hline Soluvit N & $2.5 \mathrm{~mL}$ & & $8.4 \mathrm{~mL}$ \\
\hline Vitalipid N Infant & $10 \mathrm{~mL}$ & & $36.6 \mathrm{~mL}$ \\
\hline \multicolumn{4}{|c|}{ ClinOleic (Baxter Healthcare, Australia) formulations } \\
\hline Contents & $\begin{array}{l}45 \mathrm{~mL} \text { syringe } \\
\text { For } \leq 1 \mathrm{~kg}\end{array}$ & $\begin{array}{l}90 \mathrm{~mL} \text { bag } \\
\text { For }>1 \text { to } \leq 2 \mathrm{Kg}\end{array}$ & $\begin{array}{l}150 \mathrm{~mL} \text { bag } \\
\text { For }>2 \mathrm{~kg}\end{array}$ \\
\hline ClinOleic & $32.5 \mathrm{~mL}$ & $65 \mathrm{~mL}$ & $108 \mathrm{~mL}$ \\
\hline Soluvit N & $2.5 \mathrm{~mL}$ & $5 \mathrm{~mL}$ & $8.4 \mathrm{~mL}$ \\
\hline Vitalipid N Infant & $10 \mathrm{~mL}$ & $20 \mathrm{~mL}$ & $33.6 \mathrm{~mL}$ \\
\hline
\end{tabular}

monitoring of triglycerides in preterm and term infants and suggest a triglyceride level of $2.8 \mathrm{mmol} / \mathrm{L}$ as the upper limit [6]. The 2015 Consensus survey revealed $62 \%$ of respondents monitor plasma triglyceride levels either routinely or in specific circumstances [3]. A retrospective review from an Australian NICU in which routine triglyceride monitoring is in place showed HT incidence of $32.5 \%$ in $23-25$ weeks and $16.1 \%$ in $26-28$ weeks. Severe HT (> $4.5 \mathrm{mmol} / \mathrm{L})$ was noted in $10 \%$ in $23-25$ weeks and $4.5 \%$ in $26-28$ weeks. HT was associated with a significant increase in mortality (unadjusted OR 3.5; 95\% CI 1.13-10.76; 0.033 ) and severe retinopathy of prematurity (unadjusted OR 4.06; 95\% CI 1.73-9.59; 0.002) on univariate analysis. Further multivariate analysis with adjustment for gestation and birthweight showed no significant association with HT [44].

\section{Prolonged PN usage}

The current formulations do not contain copper, manganese and molybdenum. Infants (e.g. post-surgical infants) who are exclusively on $\mathrm{PN}$ for long periods (>4 weeks) may be at risk of trace element deficiency such as copper deficiency, which is associated with pancytopenia and osteoporosis [6]. These can be added to the current formulations for those infants on exclusive PN for more than 4 weeks [1].

\section{$P N$ in non-tertiary neonatal facilities}

Many non-tertiary nurseries manage preterm and growth restricted term neonates, who may receive partial PN while establishing enteral feeds. As there is no clear evidence for this practice, the benefits of PN in this setting needs to be balanced against the potential risks of therapy, staff skill mix and the resource availability. Short term $\mathrm{PN}$ using peripheral preterm $\mathrm{PN}$ via peripheral cannula is appropriate for these infants if enteral feeding cannot be established by day $3-5$ of life.

\section{Discussion}

This updated consensus proposed a total of $8 \mathrm{AA} / \mathrm{dex}-$ trose formulations, 3 ClinOleic lipid/vitamin admixtures and 2 SMOFlipid lipid/vitamin admixtures to cater for the need of the majority of the NICU population in the network. Recommendations are based on the majority consensus and mostly meet the recommended nutrient intakes when administered at recommended volumes. It is important to note that the 2017 Consensus Group considered recommendations from ESPGHAN guidelines published in 2005 [6]. Future meetings are planned to review and optimise these formulations, which will consider the more recent ESPGHAN guidelines published in 2018 [45]. While the number of formulations seems large, it is expected that individual units may choose to limit their formulations based on their current practice, size, the spectrum of their NICU population and preference. In view of the large number of formulations and significant improvement in the formulations from 2012, colour coded posters, handouts and worksheets have been developed to assist the frontline staff in the safe prescription of PN. Coloured labels have been developed for clear identification of each formulation. Most facilities in the Australian and New Zealand region procure PN formulations from the same commercial pharmaceutical companies. Formulations and guidelines to standardise parenteral nutrition practice across the Australasian region have the potential to improve nutrition and clinical outcomes of neonates. Standardisation of the formulations across Australia resulted in reduced practice variation and reduced labour costs in compounding the formulations with the pharmaceutical companies passing on the cost savings to the NICUs. Other potential benefits of standardisation, such as error minimisation in PN prescribing and ordering, will be investigated prospectively.

\section{Conclusions}

The 2017 PN formulations and guidelines developed by the 2017 Neonatal Parenteral Nutrition Consensus Group offer concise and practical instructions to clinicians on how to implement current and up-to-date evidence based $\mathrm{PN}$ to the NICU population. In comparison to the previous formulations, the updated formulations have higher amino acid and other nutrients, particularly calcium and phosphate with the change from inorganic to organic phosphate. These PN solutions and guidelines have the potential to standardise the nutritional practice and improve both the quality and process of nutritional care and patient outcomes in the region. 


\section{Supplementary information}

Supplementary information accompanies this paper at https://doi.org/10. 1186/s12887-020-1958-9.

Additional file 1 Table S1. 2017 consensus formulations and comparison to recommended parenteral nutrient intakes in preterm neonates. Values are per $\mathrm{kg}$ per day, unless otherwise indicated. Table S2. 2017 consensus formulations and comparison to recommended parenteral nutrient intakes in term neonates. Values are per kg per day, unless otherwise indicated. Table S3. Suggested routine PN biochemistry orders.

\section{Abbreviations}

AA: Amino acids; AAP: American Academy of Pediatrics; Cl: Confidence Interval; ELBW: Extremely Low Birth Weight; ESPGHAN: European Society of Paediatric Gastroenterology, Hepatology and Nutrition; GOR: Grade of recommendation; LBW: Low Birth Weight; LOE: Level of evidence; NICU: Neonatal intensive care unit; NSW: New South Wales; OR: Odds Ratio; PN: Parenteral Nutrition; RNI: Recommended Nutrient Intakes; RR: Relative Risk

\section{Acknowledgements}

We thank all the frontline medical and nursing staff for providing feedback during the development of these guidelines.

\section{Authors' contributions}

SB was a core group member of the Consensus Group and conceptualized the consensus process and along with co-authors organised all the proceedings of the meetings, and drafted the initial manuscript. DO was a core group member of the Consensus Group, contributed to the concept and design of the consensus, and performed critical review of the level of evidence and grading of recommendation. TS was a core group member of the group, and revised the manuscript after preliminary editorial input. JS was a core member of the group, contributed to the concept and design of the consensus and contribution to the writings of all proceedings. GD, CSW, SEJ, NP, PP, RT, ML, AT, $J M, H R$, EJ, LD, GO, CA, VB, PK, KM, SQ, KS, GM, SM, PB, VSR, MPH, AN, RS, MW, $J X, R B, K L$ were representatives from their respective facilities, participated in the proceedings and contributed to the development of consensus guidelines. All authors approved the final manuscript as submitted.

\section{Funding}

No external or internal funding was provided for the development of these guidelines.

\section{Availability of data and materials}

Not applicable.

\section{Ethics approval and consent to participate}

Not applicable.

\section{Consent for publication}

Not applicable.

\section{Competing interests}

Authors have no competing (financial or non-financial) interests to declare.

\section{Author details}

${ }^{1}$ Royal Hospital for Women, Locked Bag 2000, Randwick NSW, Sydney 2031 Australia. ${ }^{2}$ Conjoint Lecturer, University of New South Wales, Sydney, Australia. ${ }^{3}$ Royal Prince Alfred Hospital, Sydney, Australia. ${ }^{4}$ University of Sydney, Sydney, Australia. ${ }^{5}$ Royal Hospital for Women, University of New South Wales, Sydney, Australia. ${ }^{6}$ Royal North Shore Hospital, Sydney, Australia. ${ }^{7}$ Nepean Hospital, Sydney, Australia. ${ }^{8}$ Hospital Kuala Lumpur, Kuala Lumpur, Malaysia. ${ }^{9}$ Deputy Clinical Director and Neonatal Paediatrician, The Royal Women's Hospital, Parkville, Victoria, Australia. ${ }^{10} \mathrm{~J} o h n$ Hunter Children's Hospital, Newcastle, Australia. ${ }^{11}$ Monash Children's Hospital, Clayton, Victoria, Australia. ${ }^{12}$ Liverpool Hospital, Sydney, Australia. ${ }^{13}$ Westmead Hospital, Sydney, Australia. ${ }^{14}$ The Children's Hospital at Westmead, Sydney, Australia. ${ }^{15}$ Head and Neonatal Paediatrician, Mercy Hospital for Women, Heidelberg, Victoria, Australia. ${ }^{16} \mathrm{Head}$ of Neonatology, Women's and Children's Hospital,

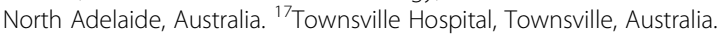

${ }^{18}$ PGCert Clinical Education, PGDip Child Health (associate), Advanced Pharmacist, Townsville Hospital, Townsville, Australia. ${ }^{19} \mathrm{Gold}$ Coast University Hospital, Southport, Australia. ${ }^{20}$ King Edward Memorial Hospital for Women, Subiaco, Australia. ${ }^{21}$ King Edward Memorial and Princess Margaret Hospitals, Subiaco, Australia. ${ }^{22}$ The Sydney Children's Hospital Network, Sydney, Australia. ${ }^{23}$ Department of Neonatology, KK Women's and Children's Hospital, Kampong Java, Singapore. ${ }^{24}$ Wellington Hospital, Wellington South, New Zealand. ${ }^{25}$ Waikato Hospital, Hamilton, New Zealand. ${ }^{26}$ Nepean Hospital, Penrith, Australia. ${ }^{27}$ Paediatric Intensivist, Sydney Children's Hospital, Sydney, Australia. ${ }^{28}$ Dunedin School of Medicine, Dunedin, New Zealand. ${ }^{29}$ University of New South Wales, Sydney, Australia.

Received: 27 September 2019 Accepted: 4 February 2020 Published online: 08 February 2020

\section{References}

1. Bolisetty S, Osborn D, Sinn J, Lui K. Australasian Neonatal Parenteral Nutrition Consensus Group. Standardised neonatal parenteral nutrition formulations-an Australasian group consensus 2012. BMC Pediatr. 2014;14:48.

2. Bolisetty S, Pharande P, Nirthanakumaran L, Do TQ, Osborn D, Smyth J, et al. Improved nutrient intake following implementation of the consensus standardised parenteral nutrition formulations in preterm neonates - a before-after intervention study. BMC Pediatr. 2014;14:309.

3. Tan A, Osborn D, Sinn J, Schindler T, Lui K, Bolisetty S. Neonatal Parenteral Nutrition Consensus Group Survey: Proceedings of the Neonatal Parenteral Nutrition Consensus Group 2015 Meeting. Sydney; 2015.

4. NHMRC Levels of evidence and grades for recommendations for developers of guidelines. 2009. www.nhmrc.gov.au/about-us/publications/guidedevelopment-evaluation-and-implementation-clinical-practice-guidelines.

5. American Academy of the Pediatric (AAP). Committee on Nutrition: Nutritional needs of the preterm infant. In: Kleinman RE, editor. Pediatric Nutrition. 7th ed. IL, USA: AAP; 2014. p. 83-121.

6. Koletzko B, Goulet O, Hunt J, Krohn K, Shamir R. 1. Guidelines on Paediatric Parenteral Nutrition of the European Society of Paediatric Gastroenterology, Hepatology and Nutrition (ESPGHAN) and the European Society for Clinical Nutrition and Metabolism (ESPEN), Supported by the European Society of Paediatric Research (ESPR). J Pediatr Gastr Nutr. 2005:41(Suppl 2):S1-87.

7. Trivedi A, Sinn JKH. Early versus late administration of amino acids in preterm infants receiving parenteral nutrition. Cochrane Database Syst Rev 2013, Issue 7. Art. No.:CD008771. DOl: https://doi.org/10.1002/14651858. CD008771.pub2.

8. Leenders EKSM, de Waard M, van Goudoever JB. Low- versus high-dose and early versus late parenteral amino-acid administration in very-low-birthweight infants: a systematic review and meta-analysis. Neonatol. 2018;113: 187-205.

9. Osborn DA, Schindler T, Jones LJ, Sinn JKH, Bolisetty S. Higher versus lower amino acid intake in parenteral nutrition for newborn infants. Cochrane Database Syst Rev 2018, Issue 3. Art. No.:CD005949. DOI: https://doi.org/10. 1002/14651858. CD005949.pub2.

10. Simmer K, Rao SC. Early introduction of lipids to parenterally-fed preterm infants. Cochrane Database Syst Rev 2005, Issue 2. Art. No.:CD005256. DOI: https://doi.org/10.1002/14651858. CD005256.

11. Vlaardingerbroek $\mathrm{H}$, Veldhorst MA, Spronk S, van den Akker $\mathrm{CH}$, van Goudoever JB. Parenteral lipid administration to very-low-birth-weight infants--early introduction of lipids and use of new lipid emulsions: a systematic review and meta-analysis. Am J Clin Nutr. 2012:96:255-68.

12. Hojsak I, Colomb V, Braegger C, Bronsky J, Campoy C, Domellöf M, et al. ESPGHAN committee on nutrition position paper. Intravenous lipid emulsions and risk of hepatotoxicity in infants and children: a systematic review and meta-analysis. J Pediatr Gastr Nutr. 2016;62:776-92.

13. Kapoor V, Glover R, Malviya MN. Alternative lipid emulsions versus pure soy oil based lipid emulsions for parenterally fed preterm infants. Cochrane Database Syst Rev 2015, Issue 12. Art. No.:CD009172. DOI: https://doi.org/10. 1002/14651858. CD009172.pub2.

14. Edward RR, Innes JK, Marino LV, Calder PC. Influence of different intravenous lipid emulsions on growth, development and laboratory and clinical outcomes in hospitalised paediatric patients: a systematic review. Clin Nutr. 2018:37:765-83.

15. Bell EF, Acarregui MJ. Restricted versus liberal water intake for preventing morbidity and mortality in preterm infants. Cochrane Database Syst Rev 
2008, Issue 3. Art. No.:CD000503. DOI: https://doi.org/10.1002/14651858. CD000503.

16. Chan W, Chua MYK, Teo E, Osborn DA, Birch P. Higher versus lower sodium intake for preterm infants. Cochrane Database Syst Rev 2017, Issue 4. Art. No.:CD012642. DOl: https://doi.org/10.1002/14651858. CD012642.

17. Peters O, Ryan S, Matthew L, Cheng K, Lunn J. Randomised controlled trial of acetate in preterm neonates receiving parenteral nutrition. Arch Dis Childhood-Fetal. 1997;77:F12-5

18. Koo WW, Tsang RC, Succop P, Krug-Wispe SK, Babcock D, Oestreich AE. Minimal vitamin $D$ and high calcium and phosphorus needs of preterm infants receiving parenteral nutrition. J Pediatr Gastr Nutr. 1989;8:225-33.

19. Devlieger $H$, Meyers $Y$, Willems $L$, de Zegher F, Van Lierde S, Proesmans W, et al. Calcium and phosphorus retention in the preterm infant during total parenteral nutrition. A comparative randomized study between organic and inorganic phosphate as a source of phosphorus. Clin Nutr. 1993;12:277-81.

20. Prestridge LL, Schanler RJ, Shulman RJ, Burns PA, Laine LL. Effect of parenteral calcium and phosphorus therapy on mineral retention and bone mineral content in very low birth weight infants. J Pediatr. 1993;122:761-8.

21. Pereira-da-Silva $L$, Costa AB, Pereira L, Filipe AF, Virella D, Leal E, et al. Early high calcium and phosphorus intake by parenteral nutrition prevents shortterm bone strength decline in preterm infants. J Pediatr Gastr Nutr. 2011:52: 203-9.

22. Fox M, Molesky M, Van Aerde JE, Muttitt S. Changing parenteral nutrition administration sets every $24 \mathrm{~h}$ versus every $48 \mathrm{~h}$ in newborn infants. Can J Gastroenterol. 1999;13:147-51.

23. Balegar VK, Azeem MI, Spence K, Badawi N. Extending total parenteral nutrition hang time in the neonatal intensive care unit: is it safe and cost effective? J Paediatr Child H. 2013:49:E57-61.

24. Matlow AG, Kitai I, Kirpalani H, Chapman NH, Corey M, Perlman M, et al. A randomized trial of 72-versus 24-hour intravenous tubing set changes in newborns receiving lipid therapy. Infec Cont Hosp Ep. 1999;20:487-93.

25. Loisel DB, Smith MM, MacDonald MG, Martin GR. Intravenous access in newborn infants: impact of extended umbilical venous catheter use on requirement for peripheral venous lines. J Perinatol. 1996;16:461-6.

26. Butler-O'Hara M, Buzzard CJ, Reubens L, McDermott MP, DiGrazio W, D'Angio CT. A randomized trial comparing long-term and short-term use of umbilical venous catheters in premature infants with birth weights of less than 1251 grams. Pediatr. 2006;118:e25-35.

27. Seguin J, Fletcher MA, Landers S, Brown D, Macpherson T. Umbilical venous catheterizations: audit by the study Group for Complications of perinatal care. Am J Perinat. 1994;11:67-70.

28. Ainsworth SB, McGuire W. Percutaneous central venous catheters versus peripheral cannulae for delivery of parenteral nutrition in neonates. Cochrane Database Syst Rev 2015, Issue 10. Art. No.:CD004219. DOl: https://doi.org/10.1002/14651858. CD004219.pub4.

29. Gazitua R, Wilson K, Bistrian BR, Blackburn GL. Factors determining peripheral vein tolerance to amino acid infusions. Arch Surg-Chicago. 1979; 114:897-900.

30. August D, Teitelbaum D, Albina J, Bothe A, Guenter P, Heitkemper M, et al. Guidelines for the use of parenteral and enteral nutrition in adult and pediatric patients. JPEN Parenter Enter. 2002;26:1SA-138SA.

31. Metjian TA, Seri I, Jew RK. Osmolarity of peripherally administered hyperalimentation and the incidence of phlebitis in the neonatal intensive care unit. Presented at 35th Annual ASHP Clinical Meeting; NV, USA; 2000 Dec 3-7.

32. Dugan S, Le J, Jew RK. Maximum tolerated osmolarity for peripheral administration of parenteral nutrition in pediatric patients. JPEN-Parenter Enter. 2014;38:847-51.

33. Hata S, Kubota A, Okada A. A pediatric amino acid solution for total parenteral nutrition does not affect liver function test results in neonates. Surg Today. 2002;32:800-3.

34. Makay B, Duman N, Ozer E, Kumral A, Yesilirmak D, Ozkan H. Randomized, controlled trial of early intravenous nutrition for prevention of neonatal jaundice in term and near-term neonates. JPEN-Parenter Enter. 2007:44:354-8.

35. Amino acids and proteins. In Koletzko B, Poindexter B, Uauy R, editors. Nutritional care of preterm infants. Basel: Karger; 2014, p. 55.

36. Hays SP, Smith EO, Sunehag AL. Hyperglycemia is a risk factor for early death and morbidity in extremely low birth-weight infants. Pediatr. 2006;118:1811-8.

37. Bottino M, Cowett RM, Sinclair JC. Interventions for treatment of neonatal hyperglycemia in very low birth weight infants. Cochrane Database Syst Rev
2011, Issue 10. Art. No.:CD007453. DOI: https://doi.org/10.1002/14651858. CD007453.pub3.

38. Sinclair JC, Bottino $\mathrm{M}$, Cowett RM. Interventions for prevention of neonatal hyperglycemia in very low birth weight infants. Cochrane Database Syst Rev 2009, Issue 3. Art. No:CD007615. DOI: https://doi.org/10.1002/14651858. CD007615.pub2.

39. Duvanel $\mathrm{CB}$, Fawer $\mathrm{CL}$, Cotting J, Hohlfeld P, Matthieu JM. Long-term effects of neonatal hypoglycemia on brain growth and psychomotor development in small-for-gestational-age preterm infants. J Pediatr. 1999;134:492-8.

40. Lucas A, Morley R, Cole TJ. Adverse neurodevelopmental outcome of moderate neonatal hypoglycaemia. BMJ. 1988;297:1304-8.

41. American Academy of Pediatrics Subcommittee on Hyperbilirubinemia. Management of hyperbilirubinemia in the newborn infant 35 or more weeks of gestation. Pediatr. 2004;114:297-316.

42. Reading RF, Ellis R, Fleetwood A. Plasma albumin and total protein in preterm babies from birth to eight weeks. Early Hum Dev. 1990;22:81-7.

43. Zlotkin SH, Casselman CW. Percentile estimates of reference values for total protein and albumin in sera of premature infants ( $<37$ weeks of gestation). Clin Chem. 1987;33:411-3.

44. Sinclair R, Lui K, Bolisetty S. Hypertriglyceridaemia in extremely preterm infants receiving parenteral lipid emulsions. Presented at 21st Annual Congress of Perinatal Society of Australia and New Zealand; Canberra; 2017 April 2-5.

45. Mihatsch W, Shamir R, van Goudoever JB, Fewtrell M, Lapillonne A, Lohner $S$, et al. ESPGHAN/ESPEN/ESPR/CSPEN guidelines on pediatric parenteral nutrition: Guideline development process for the updated guidelines. Clin Nutr. 2018:37(6 Pt B):2306-8.

\section{Publisher's Note}

Springer Nature remains neutral with regard to jurisdictional claims in published maps and institutional affiliations.

\section{Ready to submit your research? Choose BMC and benefit from:}

- fast, convenient online submission

- thorough peer review by experienced researchers in your field

- rapid publication on acceptance

- support for research data, including large and complex data types

- gold Open Access which fosters wider collaboration and increased citations

- maximum visibility for your research: over $100 \mathrm{M}$ website views per year

At BMC, research is always in progress.

Learn more biomedcentral.com/submissions 